\title{
A TIME TO DANCE
}

\author{
Tony Angelo, ${ }^{*}$ Jessica Kerr ${ }^{* *}$ and Bayley Roylance ${ }^{* * *}$
}

There is, as is declared in Ecclesiastes, a time for everything and in particular "a time to dance", "a time to rejoice", and "a time where every person should eat and drink and enjoy the good of their labours". ${ }^{1}$ The three authors here join celebrating the service of their colleague, mentor and friend by tendering some comparative comments on the law of Seychelles.

\section{INTRODUCTION}

The completion of 40 years' service to this University and to this Faculty is truly something to celebrate. The purpose of this article is to participate in that celebration and to present some thoughts from recent and proposed reforms of the law of the Republic of Seychelles, ${ }^{2}$ with particular reference to the areas of academic interest of Bill Atkin. Three areas are considered: defamation in Part II, family law matters in Part III, and alternative dispute resolution (ADR) in Part IV.

The comparative context of the chosen topics is Seychelles, which having experienced double colonisation by the French and the English, now combines in one micro island jurisdiction "both continental ('civil law') private law and 'common law' public law with judicial institutions and procedural and evidential law reflecting significant assimilation of Anglo-American legal mechanisms". 3

* Professor of Law, Victoria University of Wellington.

** BA/LLB(Hons) (VUW), LLM (Yale), Seychelles Financial Intelligence Unit.

*** BA/LLB (VUW).

1 Ecclesiastes 3. The enigmatic title also reflects the writing of a leading Seychelles lawyer and Anglican canon lawyer of the Mascareignes area. See Bernard Georges A Time to Dance (Melrose Books, Cambridgeshire, 2011).

2 For an overview of the legal system of Seychelles, see Jessica Kerr "Finding the Law in Seychelles" (January/February 2015) GlobaLex <www.nyulawglobal.org>.

3 Mathilda Twomey "The Parts That Make a Whole? The Mixity of the Laws of Seychelles" in Anna Koppel, Mohamed Y Matter and Vernon Palmer (eds) Mixed Legal Systems, East and West: Newest Trends and Developments (Ashgate, Surrey, 2014) 55 at 55, citing Vernon Palmer (ed) Mixed Legal Systems Worldwide: The Third Legal Family (Cambridge University Press, Cambridge, 2001). 


\section{A Defamation}

In Seychelles there have been, and continue to be, many challenges in the field of defamation. The Civil Code provides expressly that the law of civil defamation is the law of England; that is to say, the law of England as at 1976, the time when the Civil Code was promulgated. ${ }^{4}$ This has raised a number of academic questions as well as important practical ones. For instance, is the reference to the law of England a reference to the substantive legal principles only? Or does it relate also to the procedure? Or to the remedies that can be provided? And what of the period of limitation?

\section{B Family Law}

The biggest challenges in the civil law are undoubtedly in the field of family law, and in relation to the status of children and domestic partners both inter vivos and on succession. If the goal is equality - and there is no reason to doubt that it is, because of the constitutional provisions, ${ }^{5}$ the fact of ratification by Seychelles of all major human rights documents and also the commitment to the South African Development Community - the current law and practice is far from equal in outcome. The challenge is to develop the law from that of Napoleon to the needs of Seychelles in the 21st century.

\section{Alternative Dispute Resolution}

Informal approaches to problem-solving, drawing on personal connections and community experience, may be second nature on the islands, but a litigious streak in Seychelles society can escalate a private matter into a public saga, and the civil courts struggle to bear the load. There is ample space within the legislative architecture for ADR practice, and recent mediation reforms reflect acceptance of the need to look proactively to alternatives to litigation. Whether a jurisdiction of the size of Seychelles has the resources and patience to develop significantly in that direction in practice remains to be seen.

\section{DEFAMATION}

The Seychelles Court of Appeal said it best in Laporte $v$ Fanchette, when it described the law of defamation in Seychelles as "dynamic". ${ }^{6}$ Claims in defamation find their basis in art 1383(3) of the Civil Code of Seychelles, which states that: "The provisions of this article and of article 1382 of this Code shall not apply to the civil law of defamation which shall be governed by English law". It is this foundational provision that has drawn much comment from the courts of Seychelles. The

4 This is the current law. The rule that the civil law of defamation should be the English law was originally introduced into the Seychelles system on 3 May 1948 by the Defamation Ordinance.

5 The Constitution of the Republic of Seychelles, arts 16 ("Every person has a right to be treated with dignity worthy of a human being") and 27 ("Every person has a right to equal protection of the law ... without discrimination on any ground except as is necessary in a democratic society").

6 Laporte v Fanchette (2013) SLR 593 (CA) at [1]. 
provision makes defamation one of the few causes of action which are based in English law rather than arts 1382-1386 of the Civil Code which govern other delictual actions. ${ }^{7}$ This places Seychelles in the position of being a "mixed jurisdiction with French tort law but English defamation rules and a Constitution recognising the right to freedom of expression". ${ }^{8}$ The "dynamic" complexity that results is aptly illustrated by reference to some key Seychelles defamation cases.

\section{A Applicable Law}

The scope of art 1383(3) has been often discussed in judgments of the Seychelles courts. The courts have had to determine the legal principles, remedies and procedural law applicable to defamation claims.

\section{Substantive law}

The distinct position defamation claims have relative to claims in "fault" has been well-defined. Claims in defamation are not claims in delict under the Civil Code. The concepts which mirror the French Civil Code therefore do not apply. Certainly, the Court of Appeal in Seychelles Broadcasting Corporation v Barrado rejected any suggestion that the provisions of the Seychelles Civil Code, and not English law, could apply in cases of defamation. ${ }^{9}$

The Seychelles Court of Appeal has also held that the existence of a separate regime for defamation claims does not oust actions outside the scope of defamation. ${ }^{10}$ Any written or spoken word which does not amount to defamation, but still causes harm, may be compensated for under art 1382(1), the article of the Civil Code which provides the foundation for claims in delict. For example, while the law of defamation is not considered able to grant relief for purely abusive and insulting language, ${ }^{11}$ redress may be sought in delict. This was the case in Laporte v Fanchette. The defendant, Mr Fanchette, got into an altercation with Mr Laporte after being denied entry to the casino managed by Mr Laporte. During the altercation Mr Fanchette said to Mr Laporte in Creole "it's a damn good thing that your child has died". ${ }^{12}$ A claim that the spoken words caused "pain,

7 Articles 1382-1386 provide the basic law of tort for Seychelles. The articles are closely related to arts 1382-1386 of the French Civil Code. See Laporte v Fanchette, above n 6, at [10]; and Civil Code of Seychelles, art 1383(2).

8 Laporte $v$ Fanchette, above n 6, at [1].

9 Seychelles Broadcasting Corporation v Barrado (1993-1994) SCAR 308 at [11].

10 Laporte v Fanchette, above n 6, at [11].

11 At [1].

12 At [2]. [The statement was made in Creole: "I bon ou piti in bez mor"]. 
suffering anguish [and] distress" amounting to a fault in law was allowed. ${ }^{13}$ Simply, actions in defamation and other actions in delict stand as distinct substantive regimes.

\section{Remedies}

A similar approach has been taken in the Seychelles courts to the remedies available for defamation. In Seychelles Broadcasting Corporation v Barrado, the Court of Appeal held that damages are not to be assessed in terms of the Civil Code, but instead should be assessed in terms of the remedies available under English law. ${ }^{14}$ In that case, the trial Judge had erred by awarding separate damages for delict under the Civil Code when assessing the damages Ms Barrado, the President's personal assistant, should receive for a political broadcast that had accused her of being corrupt and of having siphoned off the rental proceeds of state property. This follows the reasoning noted by Ayoola JA that the right cannot be separated from the remedy and that it would be "untidy and absurd to define the cause of action by English law while determining the remedy by the Civil Code". 15

\section{Procedural law}

Because defamation is subject to law separate from the rest of the matters in the Civil Code, the courts in Seychelles have had to determine how far this separation extends. Specifically, the courts have had to determine whether the exception is only applicable to the substantive law and not to the procedural law. With the finding in Biscornet $v$ Honoré by Sauzier J that "English law" refers to not only the substantive law of defamation but also the procedural rules of defamation, ${ }^{16}$ the position might initially appear to have been settled.

However, more recently, in Christ v Kurtz, the Court of Appeal took the view that the Civil Code only requires defamation claims to be subject to the substantive English law and not to the English procedural law. ${ }^{17}$ The Court considered that there was no express legislative direction mandating the application of English procedure and that, in its context, art 1383(3) relates only to "a body of substantive rules". ${ }^{18}$ This position is supported by Gappy v Barallon where the Court of Appeal held "the mode and manner of proof ... remains the prerogative of the Republic of Seychelles and its Courts to regulate and decide upon". ${ }^{19}$ The particular concern in Gappy v

13 At [11].

14 Seychelles Broadcasting Corporation v Barrado, above n 9, at [36]-[37].

15 At [72].

16 Biscornet v Honoré (1982) SLR 451 (SC) at 454.

17 Christ v Kurtz (2014) SLR 531 (CA).

18 At [12].

19 Gappy v Barallon (2006-2007) SCAR 231 at [8]. 
Barallon related to the proof of defamation in Creole, one of the official languages of Seychelles. ${ }^{20}$ At a football match, the defendant called the plaintiff "voler pick-up" in front of a number of people. The statement would have been understood by those present as alleging the plaintiff had stolen the defendant's son's pick-up truck. The Court noted that under English procedural law, the Creole words would be treated as being spoken in a foreign language but held that in defamation cases in Seychelles, Creole and French were not to be treated as foreign languages and alleged defamatory statements in those languages would not be required to be proved by a sworn interpreter. ${ }^{21}$ The procedure for claims of defamation is therefore currently that of Seychelles law.

\section{Time}

The courts of Seychelles have also had to resolve the question of whether the "English law" referred to in art 1382(3) means "the English law of defamation as it stood on 1st January 1976" or the "English law of defamation with all its developmental changes as it stands today".22 Here, the Supreme Court, in Prea v Seychelles People Progressive Front, described these two positions as that of a "strict constructionist" and "intention seeker" respectively. ${ }^{23}$ In Prea, the Supreme Court favoured an approach which imported the growing English law of defamation, using that body of law to determine the liability of the Seychelles People Progressive Front for publishing a newspaper article that accused the plaintiff, a member of the National Assembly, of stealing 30 ducks that were to be sold in a church fundraising fair. However, this view of the Supreme Court in Prea is not consonant with that taken in other cases. On numerous occasions, the Seychelles courts have determined that the provision instead exists in a "time warp frozen at circa 1 January 1976 when the amended Civil Code came into effect", ${ }^{24}$ and that the courts "are unfortunately forced to look at old authorities and tattered and old editions ... of Gatley on Libel and Slander"25 in applying defamation law in Seychelles.

The "time warp" that exists around defamation law in Seychelles has been considered by the courts to have considerable implications in light of modern technological developments. In Christ v

20 Constitution of Seychelles, art 4.

21 Gappy v Barallon, above n 19, at [16].

22 Prea v Seychelles People Progressive Front (2007) SLR 108 (SC) at 123. Professor Chloros in his commentary on the Seychelles Civil Code (AG Chloros Codification in a Mixed Jurisdiction: The Civil and Commercial Law of Seychelles (North Holland Publishing Company, Amsterdam, 1977)) noted at 135, $n$ 246, that "the relevant wording adopted in the Code is to adopt the English law of defamation as it stands, at any given time".

23 At 123 .

24 Christ v Kurtz, above n 17, at [9]. See also Biscornet v Honore, above n 16. Contrast Kim Koon v Wirtz (1976) SLR 101 in which it was held that the law of defamation applicable in Seychelles by virtue of art 1382(3) is the law in force in the United Kingdom on 31 October 1975.

25 Christ v Kurtz, above n 17, at [9]. 
Kurtz, the Court of Appeal observed that the English defamation law as at 1 January 1976 potentially does not have the capacity to deal with modern advances. The Court specifically commented that "the law of defamation needs to be urgently addressed as the issue of publication is live given the technological changes brought by the internet". ${ }^{26}$ This was also a matter discussed in Prea, where the Supreme Court noted that the English law on this topic was developed in "an age before the advent of internet, television, mobile phones, constitutionalism and free speech" meaning the law would be challenged by the "multi-media knowledge-based global society and the changing needs of time and jurisprudence". 27

\section{$B$ Constitution and Defamation}

Article 22(1) of the Constitution of Seychelles protects freedom of expression stating:

Every person has a right to freedom of expression and for the purpose of this article this right includes the freedom to hold opinions and to seek, receive and impart ideas and information without inference.

This right is subject to "such restrictions as may be prescribed by a law and necessary in a democratic society" pursuant to particular interests provided for in art 22(2)(a)-(f).

\section{Civil defamation}

The existence of this protection in the Constitution has had an impact on how civil defamation has been approached in Seychelles. In Lalanne v Regar Publications Pty Ltd, the Court considered that the applicability of English decisions might be limited by the existence of the protection of freedom of expression. ${ }^{28}$

\section{Criminal defamation}

The presence of the Constitution perhaps has been more noticeably felt in relation to criminal defamation. The Penal Code of Seychelles provides for a criminal offence called "libel". Section 184 of the Penal Code reads:

Any person who by print, writing, painting, effigy, or by any means otherwise than solely by gestures, spoken words or other sounds, unlawfully publishes any defamatory matter concerning another person, with intent to defame that other person, is guilty of a misdemeanour termed "libel".

Appeals on this provision have often focused on its constitutionality. The Court of Appeal in Sullivan $v$ Attorney-General noted that: ${ }^{29}$

26 At [10].

27 Prea $v$ Seychelles People Progressive Front, above n 22, at 122.

28 Lalanne v Regar Publications Pty Ltd (2006) SLR 101 (SC) at 116.

29 Sullivan v Attorney-General (2014) SLR 417 at [16]. 
Since the enactment of the 1993 Constitution, there is no doubt that offences such as criminal libel, seditious libel, scandalising the court and other allied offences need to be scrupulously examined in the light of the constitutional provision for the right to freedom of speech. Be that as it may, these offences have survived in this country presumably under permissible exceptions under the Constitution. It is the constitutional permissibility of these exceptions that is now in issue.

The Court of Appeal upheld the decision of the Constitutional Court that the offence under s 184 of the Penal Code was a "restriction as may be prescribed by a law and necessary in a democratic society" and therefore allowable by virtue of art 22(2)(b) of the Constitution "for protecting the reputation, rights and freedoms or private lives of persons". ${ }^{30}$ Ultimately the Court did not determine whether the prosecution of the defendant for displaying a photograph on his car's back windscreen of the Minister of Environment with "a Hitler moustache"31 accompanied by the word "Traitor" was constitutionally sound as the matter had not yet been tried. ${ }^{32}$

\section{A New Act}

The complexities faced by civil defamation claimants have triggered calls for reform in some judgments. Particularly, in the case of Prea, the Supreme Court noted that: ${ }^{33}$

Before answering this fundamental question [of whether to apply the English law of defamation as it stood when the Seychelles Civil Code came into force], one should firstly find out what was the intention of the makers of the Civil Code in incorporating the provision under article 1383(3) for the importation of English law of defamation? To my mind, their intention should have been to make it a temporary or transitional measure in order to govern our law of defamation, until we enact our own legislation to replace it. Undoubtedly, they must have intended to do so, in the hope that one day in future we would replace the foreign law with our indigenous one and make it a permanent source or feature in the body of our civil law jurisprudence.

Consistency of decisions, speed of resolution and advancement of law with the rest of the world should be the cornerstone of any civil system of justice. Our civil law of defamation is not an exception to it. Our law of defamation, as presently constituted, fails on those counts leading to uncertainty in the area of defamation law and practice and inconsistency of judicial thoughts, approaches and decisions in ascertaining the liability and in the assessment of quantum of damages.

30 At [3].

31 At [2]

32 At [34].

33 Prea v Seychelles People Progressive Front, above n 22, at 120-121. 
The path forward that appears to be envisaged in cases such as Prea is the enactment of a Defamation Act incorporating local values and accounting for local conditions; a path that New Zealand took when the Defamation Act 1992 and its predecessor were enacted. Whether this direction is appropriate for Seychelles and whether Seychelles might learn anything from the New Zealand experience are both topics that warrant further consideration.

\section{FAMILY MATTERS}

\section{A Introduction}

The particular context for the family law discussion is the social environment of Seychelles, ${ }^{34}$ where most stable domestic relationships are those of persons who are not married to each other. The consequence is that the majority of children are born outside of wedlock. Taking equality of property rights in domestic partnerships and the equality of rights of all children as the goal, the question is how the law might be satisfactorily reformed to provide for such equality.

The first area for consideration is domestic relationships and the property rights of those living in stable relationships (en ménage) other than marriage.

The second concern is the status of children; that is to say, the legal position of ex-nuptial children vis-à-vis their parents, inter vivos and in succession. The Code Napoléon of 1804 dealt with the rights of legitimate children, legitimated children, adulterine children and incestuous children. Seychelles currently retains the distinction between nuptial and ex-nuptial children, ${ }^{35}$ and has specific provisions for the rights of adulterine children in succession.

Consideration will also be given in this Part to the rights of de facto partners and children in succession.

\section{B Domestic Relationships and Property Rights}

The Matrimonial Causes Act 1992 provides specifically a discretion for the Supreme Court to alter spousal property rights at the time of dissolution of a marriage. ${ }^{36}$ There is no such provision in

34 For contextual material, see Marion Benedict and Burton Benedict Men, Women and Money in Seychelles (University of California Press, Berkeley, 1982); Doris Atayi and Eugene Madejski A study on the Situation of Families and its Support Systems in Seychelles (Ministry of Social Development and Culture, Mahé, 2012); The Family Tribunal: 15 Years of Existence (Department of Social Affairs, Mahé, 2013); and Gender and Law Manual (Ministry of Social Affairs, Community Development and Sports, Mahé, 2012).

35 For example Civil Code, arts 312-342.

36 Matrimonial Causes Act 1992, s 20(1):

[In the context of divorce, nullity or separation proceedings] the court may, after making such inquiries as the court thinks fit and having regard to all the circumstances of the case, including the ability and financial means of the parties to the marriage - 
the case of the termination of a de facto relationship. Where the property of those in a de facto relationship is held in the name of only one of the parties, ${ }^{37}$ the best that the non-title holder can hope for is an award under the unjust enrichment provisions of the Civil Code. There has been some indication in the courts of a desire to move the system to one not unlike the position with constructive trusts at the Common Law, but this is not conceptually possible under the Civil Code system and to date has been rejected by the highest court. ${ }^{38}$

The French law that was extended to Seychelles in 1808 provided for a number of property regimes, but they affected only married couples. The relevant provisions of the Seychelles Civil Code were repealed in 1948 by the Status of Married Women Ordinance and, to the extent the situation is now covered by legislation, the law is in the Matrimonial Causes Act of 1992. There is nothing to preclude a private contractual arrangement in the nature of a marriage settlement, but no regimes are provided for in the legislation. The default position is therefore separation of property. It is against that background that s 20 of the Matrimonial Causes Act becomes relevant. It is a provision for redressing property imbalance statutorily. It is clearly a useful provision but it is far from providing the presumed equality of property rights that is found in a number of other legal systems. ${ }^{39}$ Further, it requires litigation to establish a right to share in the property held in someone else's name; the person with the vested legal right is in the dominant position at the time of the dissolution of the marriage.

There is another provision, in the Status of Married Women Act 1948, that enables the court to make a declaration as to property ownership during the course of a marriage. ${ }^{40}$ No specific provision is made for the determination of the property rights in a subsisting de facto relationship.

(g) make such order, as the court thinks fit, in respect of any property of a party to a marriage or any interest or right of a party in any property for the benefit of the other party ...

37 As a matter of practice immovable property is more likely than not to be in the name of the male partner alone.

38 AH Angelo and Ashleigh Allan "Common Law Equity in a Civil Law Country" (2013) 44 VUWLR 427.

39 For example the Property (Relationships) Act 1976 (NZ), s 11.

40 Status of Married Women Act 1948, s 21:

(1) In any question between husband and wife as to the title or possession of property, either party ... may apply by petition in a summary way to a Judge.

(2) The Judge may make such order, direct or make such inquiry, and award such costs as he shall think fit. 
In the current discussions concerning the reform of the Civil Code, ${ }^{41}$ consideration has been given to extending both s 20 of the Matrimonial Causes Act and s 21 of the Status of Married Women Act to those living in stable de facto relationships. It is likely that the reference in any reform will be to equity in property rights rather than to an extension of the rights of married couples to unmarried couples. In other words, the reform would address property rights rather than marriage rights.

In considering the better provision for determining the property rights of those in de facto relationships, the focus is on domestic relationships which are characterised by their stability and continuity. Suggested factors which would support a finding of stability and continuity are that the relationship has continued for at least three years, that a child has been born of the relationship, and whether the parties have acquired property in their joint names. It is thought that the holding of property in joint names is likely to be the most reliable indicator because it is reported to be a common practice and is particularly evident in respect of the acquisition of homes that are purchased with mortgage finance. It may well be that the legislator will indicate a number of factors which may raise presumptions, but which in the end will simply be indicators for the court when it exercises its discretion to determine whether the domestic relationship is one of stability and continuity.

\section{Status of Children}

The Code in many articles distinguishes between children born of a marriage and those born outside of marriage. For instance, arts 331 to 342 all fall within a Chapter entitled "Illegitimate Children"; the "Irregular Succession" rules in arts 756 to 760 deal specifically with the rights of "natural children".

Hence against the background of a constitutional right to equal protection of the law and Seychelles international obligations, consideration is being given to a new art 370 in the Civil Code. ${ }^{42}$ The new article would state in clear terms that all children have equal status at law and "the associated rule" that in matters relating to a child, the welfare and best interests of the child are always the paramount consideration.

41 A revision of the Civil Code of Seychelles was commenced on 6 May 2013. The Committee has met regularly in open forum since May 2013. In April 2015, having completed a review of all provisions of the Code, the Committee went into closed discussion on the report of the Committee, which is to be presented in December 2015.

42 Currently the article is vacant. The Children Act 1982, s 2A(1), provides "Whenever a court or tribunal determines any question with respect to the upbringing of a child, the child's wellbeing shall be its primary consideration". 


\section{Succession}

\section{The law}

These matters all flow over into the field of succession. Not only is there a question of the rights of the children of the deceased, which at present are unequal, but there is also the question of the surviving partner who, if not a surviving spouse, has no right in the partner's succession. ${ }^{43}$

The current law provides that in the case of an intestacy, property will descend to children and other lineal descendants, and then to ascendants and collaterals. ${ }^{44}$ In competition with them is the surviving spouse who, in the presence of descendants or ascendants, will take the personal chattels and half of the estate. ${ }^{45}$ In the absence of descendants or ascendants the surviving spouse will take all the property. ${ }^{46}$ This provision for intestate succession is echoed in, and to a degree reinforced by, the provisions relating to testation. The rights of testation are restricted when the deceased is survived by children. In the presence of children there will be a reserved portion which cannot be disposed of by will. ${ }^{47}$ There is no protection in the context of testacy for a surviving spouse. If the surviving spouse does not by will receive property that is not covered by the portion reserved for children, he or she will receive nothing.

The principle is that all children are to be treated alike. Article 745 of the Civil Code provides that:

Children or their descendants succeed to their father and mother, grandfathers and grandmothers or other ascendants without distinction of sex or primogeniture, even if they are born of different marriages.

They take in equal shares, and per head, if they are all of the first degree and inherit in their own right; they take per stirpes when all or some of them inherit by representation.

That provision is modified by the rules on "irregular succession". ${ }^{48}$ Article 757 provides:

The natural child shall have, in general, and in respect of his father and mother and other ascendants as well as his brothers and sisters and other collaterals, the same rights as the legitimate child.

However art 760 states:

43 Unless there is a will which makes a gift to that partner.

44 Civil Code, art 731.

45 Civil Code, art 767

46 Civil Code, art 766

47 Civil Code, arts 913 to 917.

48 That is, children born out of wedlock, the surviving spouse and the State. See Civil Code, arts 756 to 769. 
Natural children, whose father or mother, at the time of their conception, was married to another person, shall be entitled to succeed together with any legitimate children of that marriage; in that case, however, the share of each such natural child shall be one half of what it would have been if all the children of the deceased had been legitimate.

A strong body of opinion in Seychelles is against any change to this rule relating to the status of adulterine children. The reason given is that the adulterine child represents a breach of the marriage contract, and in honouring that contract protection should be given to the children born of the marriage. Only limited protection should be given to those born of the adulterous relationship.

\section{Reform possibilities}

One way to protect the rights both of de facto partners and of ex-nuptial children in succession matters would be simply to amend the relevant articles to eliminate all reference to discrimination between children on the grounds of birth status, and to extend the rights of surviving spouses to the surviving partners of de facto relationships.

A more radical, and ultimately much simpler, distribution system was that raised in 2013 in a Constitutional Court case that considered the constitutionality of the reserved share provisions on succession. ${ }^{49}$ The challenge in that case was in relation to freedom of disposition of property.

Article 26(1) of the Constitution provides that every person has a right to property and the right to acquire, own, peacefully enjoy and "dispose of property". In art 26(2) "the exercise of the right under clause (1) may be subject to such limitations as may be prescribed by law and necessary in a democratic society - (a) in the public interest". Article 913 of the Civil Code restricts the right to deal with property by way of will. It says:

[A] gift inter vivos or by will shall not exceed one half of the property of the donor, if he leaves at death one child; one third, if he leaves two children; one fourth, if he leaves three or more children; there shall

be no distinction between legitimate or natural children except as provided by article 915-1.

By will, the deceased had left property to beneficiaries other than his children; the descendants claimed the property reserved to them by art 913 . The issue was therefore joined between the defenders of the testamentary disposition and the heirs who had reserved rights under art 913 . The defenders of the disposition in the will referred, among other things, to the manner in which English legislation provided protection for close family members within the context of testamentary freedom. ${ }^{50}$ The question was whether art 913 was a limitation on the property rights protected under art 26 of the Constitution, and in particular whether it was a limitation "prescribed by law" and

49 Durup v Brassel (2013) SLR 259 (CC).

50 The legislation was the Inheritance (Provision for Family and Dependents) Act 1975. That legislation historically drew on the experience of the New Zealand family protection legislation - which in turn had drawn on civilian law principles found in the Scottish succession law. 
whether any such limitation was necessary "in a democratic society ... in the public interest". Further context was provided by art 32(1) of the Constitution which states that "the State recognises that the family is the natural and fundamental element of society and the right of everyone to form a family and undertakes to promote the legal, economic and social protection of the family".

Having established a prima facie case of restriction on the right to property, the burden shifted to the State and the descendants to prove that the limitations on testamentary freedom were constitutional. The Court had no difficulty in determining that the restrictions in art 913 were restrictions on the right to dispose freely of property, and further that they were "prescribed by law". The more difficult question was whether the limitations were "necessary in a democratic society and in the public interest". The case of Silver $v$ The United Kingdom ${ }^{51}$ was cited in support of the contention that the restrictions were constitutionally valid. An earlier decision of the Seychelles Court of Appeal had held that "necessary in a democratic society" implied the existence of a "pressing social need". 52 Taking into account art 205 of the Civil Code (relating to mutual support between spouses) and the intestacy provisions of art 745 of the Civil Code, the Court addressed the question of "pressing social need" for the restriction in art 913. In conclusion the Court held that the limitation: ${ }^{53}$

... in art 913 of the Civil Code affords the widest possible legal, economic and social protection to the family, which is the natural and fundamental group unit of society and is therefore in the public interest under art 26(2)(a) of the Constitution.

It was also held: ${ }^{54}$

... that there is also a "pressing social need" to protect the reserved heirs from total and unjust disinheritance from a succession, in which they are entitled, to the benefit of third parties.

A consequence of the decision has been that consideration is now being given to moving from a situation of limited testamentary freedom to one of total testamentary freedom, subject only to some legislative protection for those near to the deceased. There seems to be general agreement in Seychelles that there should be a right to adequate maintenance for a surviving partner and the children and parents of the deceased, where any of them was wholly or partly dependant on the deceased.

A shift in principle from one of limited testamentary freedom to one of full testamentary freedom would raise the question of whether there is any continuing need for the rules on the giving

51 Silver v The United Kingdom (1983) 5 EHRR 347 (ECHR).

52 Seychelles National Party v Michel (2010) SLR 216 (CA) at 234.

53 Durup v Brassel, above n 49, at [43].

54 At [46]. 
of gifts. The Seychelles Civil Code retains the elaborate French Civil Code provisions on gifts. A prime purpose of that system is to protect the inheritance rights of members of the immediate family of the deceased. The powers of testation in the presence of children or surviving spouse are limited, and the control of gift giving inter vivos is one way to ensure that property is available to satisfy the reserved shares of successors at the time of the family member's death. If a regime of testamentary freedom were introduced, much of the law on gifts and their "calling back" 55 to satisfy the interest of reserved heirs could be repealed. Intestacy succession laws would remain unaffected, subject only to the strengthening of the rights of surviving partners and ex-nuptial children.

Much of the debate and drive towards equality of rights within the family is reminiscent of the developments in New Zealand in 1970 with the Status of Children Act 1969, and in 1977 with the commencement of the Matrimonial Property Act 1976. ${ }^{56}$ The difference in Seychelles is the French Civil Code background which provides the common law (droit commun) for Seychelles.

\section{ADR IN SEYCHELLES}

\section{A Introduction}

In 2010, the Court of Appeal opined that "un mauvais arrangement est mieux qu'un bon jugement". 57

"Alternative" or "appropriate" methods of dispute resolution (ADR), in the sense of organised alternatives to civil litigation, are both familiar and alien to Seychellois legal culture. In a jurisdiction with approximately 55 attorneys, 20 judicial officers and one new law school, the formal aspects of ADR - accreditation bodies, professional regulation, private institutions - remain essentially absent. Ordinary civil disputes are tried in open court, in the hands of attorneys-at-law and judges who are appointed on the Commonwealth model. Court fees are payable at levels that do not materially discourage the institution or protraction of litigation; attorneys could until 2012 benefit from an appearance-based legal aid scheme. ${ }^{58}$ There is no mechanism for increased costs orders, and little sanction for abuses of process. Cases may be "mentioned" 10 times - or more without substantive progress, and many litigants become accustomed to minimal information from counsel.

55 Civil Code of Seychelles, arts 920-930.

56 In 2002, formal provision was made for de facto relationships and also to establish the relationship of the domestic property relationship regime to the succession regime: Property (Relationships) Amendment Act 2001 (NZ)

57 Vital v Chetty (2010) SLR 442 (CA) at 444. (A bad settlement is better than a good judgment.)

58 See the Legal Aid (Amendment) Rules 2012. 


\section{B Official Endorsement}

In 2010, the Court of Appeal endorsed ADR in emphatic terms. Having "prompted" the parties to settle an appeal by consent, the Court in Vital $v$ Chetty took the opportunity to describe the virtues of a "consensus theory which complements the conflict theory" and to urge readers to "reserve our courts for matters which genuinely could not be resolved between the parties with the assistance of counsel". 59 In the Court's view, "[e]nhanced professional practice demands that, through their specialized knowledge of the law and life, counsel should attempt to minimize litigation rather than generate it." ${ }^{60}$ The ethical obligation arising in this regard is partly reflected in the first local professional code of conduct, promulgated in 2013:61

\section{Duty to inform client about alternatives to litigation}

16. (1) At the commencement of, and during, litigation a legal practitioner shall inform his or her client of -

(a) available alternatives to pursuing litigation;

(b) any law, procedure or practice which has the prospect of a substantive advantage if the client -

(i) pleads guilty; or

(ii) takes any steps to reduce the issues, time, costs or distress involved in a proceeding.

The model of ADR presented in Vital $v$ Chetty is lawyer-driven, with emphasis placed throughout the judgment on the skill and professionalism of counsel; there is no reference to the prospect of proceeding through ADR without a lawyer's "able guidance". ${ }^{62}$ The Court of Appeal also cites its own successful interventions in previous appeals - a process observable at all levels of the court hierarchy.

Both core procedural codes of Seychelles envisage negotiated settlements with a limited degree of judicial oversight. The Code of Civil Procedure (cited and applied in Vital $v$ Chetty) requires the court to give judgment in accordance with a consent signed by both parties to any civil suit, "unless it see cause not to do so". ${ }^{63}$ The Criminal Procedure Code empowers the court to "promote reconciliation" and authorises the "settlement in an amicable way [on terms approved by the court]

59 Vital $v$ Chetty, above n 57, at 443-444.

60 At 443 .

61 Legal Practitioners (Professional Conduct) Rules 2013, r 16(1).

62 Vital v Chetty, above n 57, at 443.

63 Seychelles Code of Civil Procedure, s 131. 
of proceedings for common assault, or any other offence of a personal or private nature not amounting to felony, and not aggravated in degree...". ${ }^{4}$ The Court in Vital v Chetty, while noting the absence of a requirement to attempt mediation before filing, observed that "that does not stop parties from adopting this principle based on common sense". ${ }^{65}$

\section{$B$ ADR in Practice}

\section{Court statistics}

Despite these encouraging words, one senior practitioner estimates that only about 10 to 15 per cent of current civil disputes settle without trial (including all forms of ADR), and that of those, only a small number are reflected in consent judgments. This is in the context of a pending case load in the Supreme Court - the trial court of unlimited general jurisdiction - that has stabilised recently at about 1,000 civil cases, with approximately 750 completed in any one year. (The Magistrates' Court, the equivalent of the New Zealand District Court, has a workload of about 200 civil cases and a much healthier completion rate.) The Supreme Court has, since 2010, adopted aspirational time standards for case resolution, set at a maximum of 24 months for ordinary civil suits and 12 months for matters on the new Commercial List. However, as at December 2013, a clear majority of pending civil suits were older than two years. More than a quarter had been in the system for more than five years. ${ }^{66}$

\section{Arbitration}

Private arbitration is an accepted, though rare, method of resolving commercial and land disputes. It is comprehensively provided for in Title IX of the Commercial Code Act 1977, which reflects the text of the uniform law on arbitration proposed by the European Convention on Arbitration 1967. ${ }^{67}$ The courts have accepted the enforceability and severability of contractual arbitration clauses, consistent with English common law, within the overarching "public policy" framework of the Civil Code. ${ }^{68}$ Even where parties did not contract for arbitration, the Supreme

64 Criminal Procedure Code, s 168.

65 Vital v Chetty, above n 57, at 444.

66 See Judiciary of Seychelles Annual Report 2013 (available at SeyLII <www.seylii.org>).

67 See Omisa Oil Management v Seychelles Petroleum Co Ltd (2001) SLR 50 (SC) at 55, quoting Chloros, above $\mathrm{n} 22$, at 156 .

68 See for example Intour SRL v Emerald Cove (2000) SLR 21 (SC) (citing Beitsma v Dingjan (No 1) (1974) SLR 292) and Le Roux v Eden Island (2012) SLR 175 (SC)). See further Divino Sabino "Legal and Policy Considerations for Effective Alternative Dispute Resolution in Seychelles" (paper delivered at the Bar/Bench Symposium on the Role of ADR in Access to Justice in Seychelles, Baie Lazare, Seychelles, 29 August 2012) (published in the Law Journal of the Bar Association of Seychelles, available at Bar Association of Seychelles <www.bas.sc $>$. 
Court is empowered by the Code of Civil Procedure ${ }^{69}$ to refer cases to arbitrators on its own motion or by request - not always with happy results. Choppy $v$ NSJ Construction involved a dispute arising from a building contract with no arbitration clause. ${ }^{70}$ The case was referred by consent to a private arbitrator (a lawyer). The resulting arbitral award was confirmed by the Court, over the objection of one party, but ultimately set aside by the Court of Appeal for "obvious error", with the result that the entire case went back for trial before a different Judge.

Anecdotal evidence suggests that an average of six to 10 arbitrations are currently conducted in Seychelles per year, by private arrangement or on court direction, which are presided over by senior practitioners, retired judges or non-legal experts like valuers. There is no local specialist arbitral training and it is not a profession as such. Several senior practitioners who conduct arbitrations are also engaged by local clients to act in international arbitrations, some of which have been on a significant scale. The potential for growth in both domestic and international arbitration is clear, but it remains an essentially private field.

The most unusual feature of the Commercial Code framework is the adoption as "binding" of the provisions of the New York Convention on the Recognition and Enforcement of Foreign Arbitral Awards $1958,{ }^{71}$ to which Seychelles is not, unlike New Zealand, a party. ${ }^{72}$ The resulting position has proved uncomfortable: in Omisa Oil Management $v$ Seychelles Petroleum Co Ltd ${ }^{73}$ a standard-form application for leave to register a Swiss award had to be declined on the basis of lack of reciprocity between Convention and non-Convention states, and the procedure appears to have languished since then. Seychelles' position in this regard may be developing: in 2013, the Permanent Court of Arbitration representative in neighbouring Mauritius (which has constituted itself as an

69 Seychelles Code of Civil Procedure, s 205.

70 Choppy v NSJ Construction (2012) SCCA 14, reversing Choppy v NSJ Construction (2011) SLR 215 (SC).

71 Commercial Code of Seychelles Act, arts 146-150. Article 146 provides that "[o]n the basis of reciprocity, the New York Convention on the Recognition and Enforcement of Foreign Arbitral Awards, 1958, and the arbitral award within the meaning of the said Convention shall be binding ...". Article 148 provides that "[a]rbitral awards under the said Convention shall be recognised as binding and shall be enforced in accordance with the rules of procedure in force in Seychelles".

72 This position should not be taken to signal general resistance to arbitration as a dispute resolution mechanism, given that Seychelles is a member of the International Centre for the Settlement of Investment Disputes (which facilitates arbitral resolution of investor-State disputes), and has legislated specifically for the recognition of United Kingdom arbitral awards (see the Reciprocal Enforcement of British Judgments Act 1922), and of foreign court judgments from other jurisdictions, which may themselves reflect foreign arbitral awards (see the Foreign Judgments (Reciprocal Enforcement) Act 1961), in addition to providing the Commercial Code framework for domestic arbitration.

73 Omisa Oil Management v Seychelles Petroleum Co Ltd, above n 67. 
international arbitration hub) was invited to deliver the New York Convention Road Show in Seychelles, co-presented by a Judge of the French Cour de Cassation. ${ }^{74}$

\section{Institutional mediation}

Institutional mediation, unlike institutional arbitration, is well-established in certain contexts; it is compulsory for most complaints brought before the specialist Family Tribunal and Employment Tribunal, both of which sat outside the judiciary until 2015. When an employment grievance is filed, the (non-legal) officer who receives the file must "endeavour to bring a settlement of the grievance by mediation" before the matter proceeds to the Employment Tribunal. ${ }^{75}$ Mediated agreements in that context can be endorsed by the Tribunal as "a form of judgment by consent". ${ }^{76}$ Mirroring the top-down focus of the Court of Appeal in Vital $v$ Chetty, the Act focuses on the official rather than the parties, providing directions in the event "the competent officer is unsuccessful in the mediation". ${ }^{77}$ Time limits are very strict in theory, with only 28 days allowed in ordinary employment disputes and only 7 days where a worker is non-Seychellois. Mediation is also a mandatory first resort in most family disputes. ${ }^{78}$ The Secretary of that Tribunal (currently a law graduate) is directed to "request the parties to attend before [her] and endeavour to settle the dispute by mutual agreement without any influence being exerted by any outsider", with any mediated agreement referred to the Tribunal for approval. ${ }^{79}$ There are no published statistics for Family Tribunal mediations, but those for the Employment Tribunal indicate that more than 25 per cent of 670 disputes referred to mediation in 2013 were successfully settled, albeit only three resulted in judgments by consent. ${ }^{80}$

The Fair Trading Commission, established in 2009, has exclusive jurisdiction in consumer protection and fair competition matters. The Commission is not obliged to use ADR, but has adopted mediation in practice as an alternative to formal investigation of consumer complaints. ${ }^{81} \mathrm{It}$

74 Fedelma Smith (PCA Mauritius) and Antony Derjacques (President BAS) (PCA/ICCA New York Convention Road Show on International Arbitration, Ile du Port, Seychelles, 10 August 2013). Presentation materials available at Judiciary of Seychelles "PCA/ICCA New York Convention Road Show on International Arbitration, Palais de Justice, 10 August 2013" (10 August 2013) SeyLII <www.seylii.org>.

75 Employment Act 1995, s 61(1A).

76 Section 61(1B).

77 Section 61(1D)

78 Mediation is compulsory for all disputes within the jurisdiction of the Family Tribunal under the Children Act 1982 (including custody, maintenance and issues of consent to treatment), except applications under the Family Violence (Protection of Victims) Act 2000.

79 Children Act 1982, s 78(9)

80 National Bureau of Statistics Crime Justice \& Security Statistics (CJS 2014/Q3, 2014) at table 8.

81 The Public Service Appeal Board, constituted by ch XI of the Constitution, is another body that in practice has used negotiated alternatives to formal proceedings. 
has published detailed online guidance on its approach to conducting "telephonic", "written" and "on-site" mediations, ${ }^{82}$ and is also regularly publishing encouraging statistics on the number of successfully mediated disputes. ${ }^{83}$ Again, the Commission's self-imposed timeframe for mediation is very strict (10 working days), although the statistics suggest this limit is aspirational.

\section{Reform Initiatives: Court-Annexed Mediation}

During the tenure of Chief Justice Egonda-Ntende (2009-2014), concerted efforts were made to raise the profile of ADR and to encourage and facilitate arbitrated, mediated or negotiated resolution of disputes that would otherwise be adding to the unsustainable backlog in the civil courts. ${ }^{84}$ In 2011, a workshop on civil case management, supported by the Commonwealth Institute, produced a general consensus between Bench and Bar that ADR - particularly mediation - be encouraged, if not mandated, in disputes that would otherwise come before the courts. ${ }^{85} \mathrm{~A}$ year later, a formal symposium on ADR and access to justice was held over two days. ${ }^{86}$ Again stakeholders expressed almost unanimous support for the development of a pilot project in court-annexed mediation, particularly in commercial cases. The Chief Justice began working with local drafters and the World Bank to develop an appropriate statutory framework. In 2013, the Supreme Court (Mediation) Rules were enacted, providing a formal structure for court-annexed mediation in civil cases, and in early 2014, a senior judge and mediator from the United States spent almost a month in Seychelles training judicial officers, practitioners and public servants in mediation, and attempting to build public awareness.

The Supreme Court (Mediation) Rules, as amended in 2014 to include rules of professional conduct for mediators, ${ }^{87}$ now enable almost any pending civil dispute in the Supreme Court to be referred to mediation, either at the request of a party or on the Judge's initiative. The mediator can be any other judge, or any person authorised by the Chief Justice. The process is designed to be typically flexible and informal, on a confidential and without prejudice basis, providing maximum opportunity for negotiation between parties, with support and guidance available from the mediator

82 Fair Trading Commission Seychelles "Consumer Guidelines" <www.ftc.sc〉.

83 Fair Trading Commission Seychelles "Mediation" <www.ftc.sc>, indicating that 35 per cent of disputes sent to mediation in the first quarter of 2014 were successfully resolved.

84 See FMS Egonda-Ntende "The Contribution of Alternative Dispute Resolution Mechanisms in Enhancing Access to Justice and the Administration of Justice in Seychelles" (keynote address to the Bar/Bench Symposium on the Role of ADR in Access to Justice in Seychelles, Baie Lazare, Seychelles, 28 August 2012) (published in the Law Journal of the Bar Association of Seychelles, available at Bar Association of Seychelles <www.bas.sc>.

85 See Sabino, above n 68.

86 Judiciary of Seychelles "Symposium on the Role of ADR in Access to Justice in Seychelles on the 28th and 29th August, 2012 at the Kempinski Hotel" (5 September 2012) SeyLII <www.seylii.org>.

87 Supreme Court (Mediation) (Amendment) Rules 2014. 
and any attorneys involved. There is no additional cost to parties, at least during the pilot phase. If the mediation succeeds, the resulting agreement is entered as a consent judgment; if not, the matter is sent back for trial. The timeline is more generous than in the specialist tribunals but still tight (a default of 90 days), in an attempt to ensure that reference to mediation does not present an opportunity for delay. As for the tribunals, this timeframe has unfortunately proved aspirational so far. Uptake has been slow but steady, at around 30 cases per year.

Submission to mediation is also contemplated in the Rules which established the Commercial List in the Civil Division of the Supreme Court in April 2012. ${ }^{88}$ Once pleadings have closed in a commercial dispute, the Court must call a preliminary hearing to determine the issues in dispute "and ascertain whether the matter may be submitted to mediation". ${ }^{89}$ That process should feed into the court-annexed mediation structure established by the 2013 Rules. Historical resistance to the concept of substantive case management has, however, so far prevented this pre-trial filtering mechanism from having much impact.

Nearly all current Supreme Court Judges and several Magistrates have some formal mediation training, and several were mediating their own cases in court for years before the introduction of the Rules. However, only a handful of attorneys hold mediator qualifications, and few claim ADR within their areas of expertise. Most government officials engaged in supporting or conducting institutional mediation are not lawyers and few, if any, hold ADR qualifications. There is no specialised regulatory body and, prior to the well-attended courses organised by the Judiciary in 2014, no local training opportunities. The new LLB degree, taught by the University of Seychelles as a remote programme of the University of London, does not yet offer ADR courses. The even newer Bar course, delivered by the University on behalf of the Chief Justice, has focused in previous years on substantive domestic law (particularly the Civil Code, Constitution and procedure). A vocational component, including ethics, advocacy and ADR, is being trialled for the first time in 2015-2016. It will be interesting to see whether the new court-annexed mediation regime contributes significantly to demand for training of this kind.

\section{Future Potential}

The most commonly cited barriers to backlog reduction in the civil courts of Seychelles are outdated procedural rules and inefficient case management practices. Pervasive systemic issues of this kind can be significantly mitigated by an increased focus on party-led solutions, consistent with the basic structure of the Seychelles court system. This does however require small-scale, enabling structural reforms of the kind now being progressively introduced, coupled with a change in culture that supports informed litigants to take opportunities to engage in ADR, if necessary with the guidance of disinterested counsel. Other jurisdictions like New Zealand can lead by example, but

88 Supreme Court (Commercial List) Rules 2012.

89 Supreme Court (Commercial List) Rules, r 5(1). 
that change in culture requires local champions and visible successes. Seychelles is still taking its first steps in that direction.

\section{CONCLUSION}

The three areas commented upon in this article are all areas to which Bill Atkin has contributed both internationally and most specifically in New Zealand. It is to be hoped that some of that New Zealand experience will be able positively to inform the developments of a distant jurisdiction which is currently seeking to address inadequacies in its law in these same areas.

Happy 40th, Bill. 
